\title{
Intermédialités
}

Histoire et théorie des arts, des lettres et des techniques

Intermediality

History and Theory of the Arts, Literature and Technologies

\section{Variations sur l'insignifiant génétique : les métaphores du (non-)code}

\section{Thierry Bardini}

Numéro 3, printemps 2004

URI : https://id.erudit.org/iderudit/1005473ar

DOI : https://doi.org/10.7202/1005473ar

Aller au sommaire du numéro

Éditeur(s)

Centre de recherche sur l'intermédialitè

ISSN

1705-8546 (imprimé)

1920-3136 (numérique)

Découvrir la revue

Citer cet article

Bardini, T. (2004). Variations sur l'insignifiant génétique : les métaphores du (non-)code. Intermédialités / Intermediality, (3), 162-186.

https://doi.org/10.7202/1005473ar
Résumé de l'article

Cet article examine l'histoire de la biologie moléculaire à partir d'une perspective sémiotique sur la métaphore du « code génétique ». Celle-ci est considérée comme la catachrèse centrale d'un réseau métaphorique cybernétique développé depuis la naissance de la discipline dans les années 1950. En suivant la perspective de Paul Ricoeur, l'auteur suggère que la métaphore du " code génétique " peut produire une vérité scientifique et philosophique contre l'illusion référentielle. Cet argument est analysé à partir de la description de la partie non codante de l'ADN, entendue comme le résidu d'une métaphore qui considère l'ADN comme le médium d'un s-code, mais aussi comme l'objet d'un effet de réel/récit. Seule une multimodalité de référence pour la métaphore du code génétique pourrait rouvrir le champ de la découverte sur ces $97 \%$ de l'ADN tenus par la métaphore cybernétique originelle comme des « détails insignifiants ». 


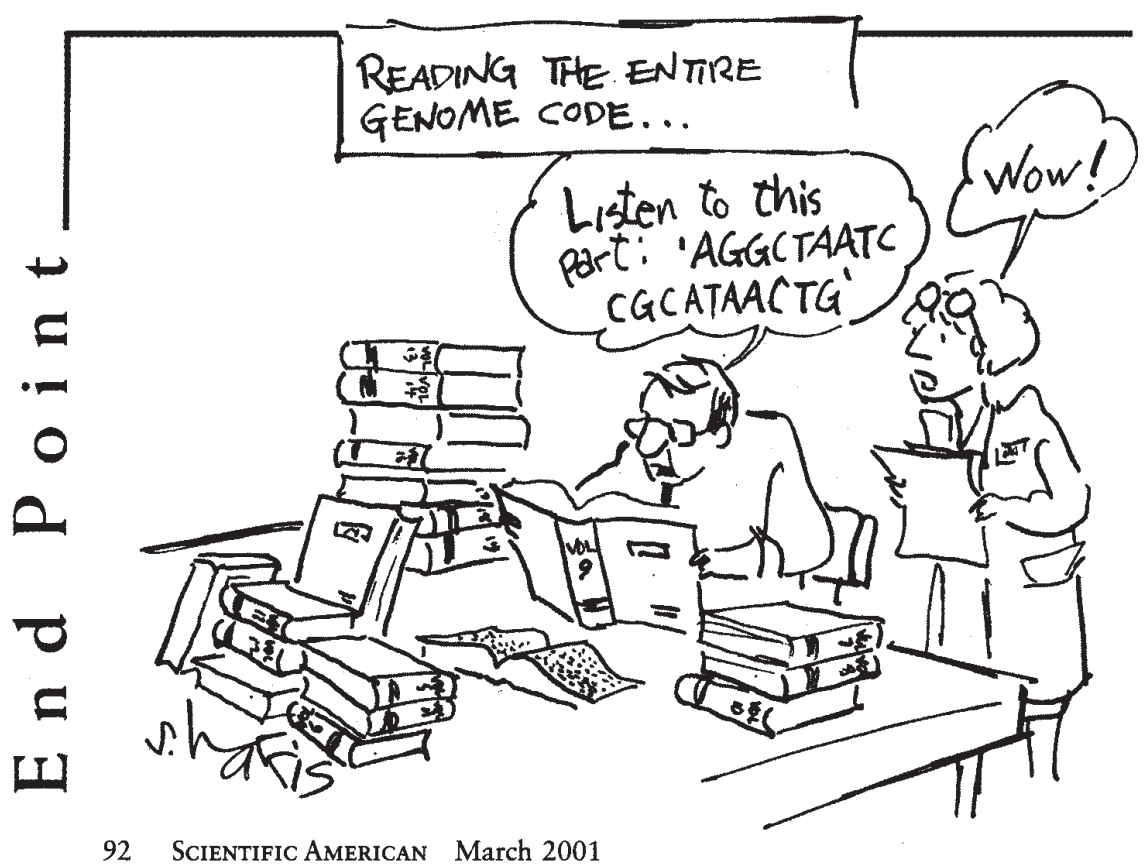

92 SCIENTIFIC AMERICAN March 2001

(C) Sidney Harris, «Reading the entire genome code ", Scientific American, vol. 284, n $^{\circ}$ 3, mars 2001, p. 92. (Avec la permission de l'artiste) 


\title{
Variations sur l'insignifiant génétique: les métaphores du (non-)code
}

\author{
THIERRY BARDINI
}

\begin{abstract}
L'ADN est un cristalloïde, il est particulièrement sensible aux rayonnements électromagnétiques. En clair c'est aussi une antenne [...] C'est pour ça que les métaphores de notre ami Dantzik ne sont que des métaphores d'écrivain, Liber Mundi, la puissance du Verbe, tout ça on est d'accord, mais il faut bien comprendre que nos cerveaux sont au livre ce que le cortex des jumelles Zorn est au méganet mondial. Cette nouvelle métaphore du réseau et de l'antenne nous indique que la prochaine révolution bio-sociale est bien à l'œuvre.
\end{abstract}

Maurice G. DANTEC ${ }^{1}$

Dans cet article, j'examine l'histoire de la biologie moléculaire et de sa notion centrale de «code génétique» à partir d'une perspective sémiotique. En contrastant divers types de regards sémiotiques, je m'interroge sur un certain nombre de pseudo-évidences constitutives des discours actuels sur la destinée de l'espèce humaine, à l'aube des grandes transformations techniques et culturelles ouvertes par la possibilité manifeste du clonage humain à relativement court terme. Parmi ces pseudo-évidences, le trope du «code génétique» et de son « décryptage » m’apparaissent fondamentaux.

Ces pseudo-évidences s'inscrivent aujourd'hui dans les phantasmes et délires du cyborg, version NASA-1961, réactualisés par les discours post-constructivistes des disciples de Donna J. Haraway: «Cyborgs do not stay still. Already in the few decades that they have existed, they have mutated, in fact and fiction, into second-order entities like genomic and electronic databases and the other

1. Maurice G. Dantec, Babylon Babies, Paris, Éditions Gallimard, coll. «La noire», 1999 , P. 535 . 
denizens of the zone called cyberspace ${ }^{2}$.» Le cyborg est. Ou comme le dit Katherine Hayles, «we became post-human ${ }^{3}$ ». Comme s'il suffisait de l'énoncer pour qu'il soit, «en fait comme en fiction». Mais dans quelle logique? Dans la bonne vieille logique de la «domination», dans ce «partage de l'étant en subjectif et objectif, du spirituel humain et du concret, mécanique inhu$\operatorname{main}^{4}$ »? Dans une logique d'appropriation de l'ultime moyen de production? Dans celle de l'ultime intermédialité, celle qui constituerait l'humain comme (inter)médium?

Si l'on peut en effet tenir l'hypothèse d'une intermédialité essentielle de l'humain à l'heure actuelle, c'est bien du fait de l'existence d'un milieu d'échange, d'une interface pour toutes ces catégories qui étaient jusqu'alors conçues dans le cadre de dichotomies inéluctables. À l'inverse, une telle interface, un tel médium permet de concevoir des équivalences, des traductions, bref des «trans-formations» entre ces domaines. Ces transformations peuvent être entendues dans le sens de la «manipulation identitaire », tant elles remettent fondamentalement en cause l'essence humaine.

Mais ces «manipulations» doivent aussi être replacées dans le cadre plus vaste de l'anthropogenèse dans l'évolution, car comme le dit Sloterdijk,

l'emprise la plus spectaculaire du mécanique sur le subjectif s'annonce dans les technologies génétiques. Car elles tirent un vaste domaine de présupposés de soi à portée des manipulations artificielles. À cela se rattache l'idée plus ou moins fantastique que l'on pourrait, à court terme, «faire des homme entiers». Dans de tels fantasmes, les biologismes primitifs rivalisent avec les humanismes et les théologismes désemparés sans que l'on puisse déceler chez les tenants de telles opinions une once de compréhension des conditions de l'anthropogenèse dans l'évolution ${ }^{5}$.

Mais si le cyborg peut (ou pourra) être «en fait comme en fiction» - ce qui sonne finalement comme «sur la terre comme au ciel» et appelle l'amen de rigueur - c'est parce qu'il existe des passages entre ces mondes, ces réper-

2. Donna J. Haraway, «Cyborgs and Symbionts: Living Together in the New World Order», dans Cyborg Handbook, Chris Hables Gray (dir.), London, Routledge Press, 1995, p. XIX.

3. Katherine N. Hayles, How we Became Post-Human, Chicago, University of Chicago Press, 1999.

4. Peter Sloterdijk, La domestication de l'être, trad. Olivier Mannonni, Paris, Éditions Fayard, coll. "Mille et une nuits», 2000, p. 82.

5. Peter Sloterdijk, La domestication de l'être, p. 84 . 
toires, ces expériences et ces pratiques. Ici, je m’attacherai à décrire un de ces passages sous la forme «symbolique» de la métaphore du «code génétique».

\section{HISTOIRE DU CODE GÉNÉTIQUE}

Dans cette première partie, j'établirai les liens historiques entre les tropes fondateurs de la biologie moléculaire et le répertoire conceptuel de la cybernétique, et plus particulièrement de la théorie de l'information de Shannon et Weaver $^{6}$. Et je commencerai par dissiper un malentendu: la cybernétique n’a pas directement influencé la biologie moléculaire naissante, ou du moins pas dans un premier temps, et certainement pas en ce qui concerne une influence qui ferait de la seconde une application des théories de la première. Comme en témoigne cette «opinion» du seul biologiste jamais invité aux fameuses rencontres de la fondation Macy, à l'origine de la synthèse cybernétique : «It was vacuous in the extreme and positively inane. Genetics did not, and at that time could not enter it at all ${ }^{7}$. »

Malgré les dangers d'une histoire individuelle du type founding father narrative, la première influence provient plutôt des réflexions d'Erwin Schrödinger dans What is Life $?^{8}$. La plupart des historiens ${ }^{9}$ s'accordent en effet pour voir dans les théories et intuitions de la physique (quantique) les origines conceptuelles de la biologie moléculaire. Si Schrödinger avait envisagé dès 1944 l'existence d'un «Morse-like code script» pour l'hérédité, les notions connexes d'«information », de "programme », d' «alphabet », de «message », ou de « texte » n’ont pas été employées par les premiers biologistes moléculaires avant 1955. Cependant, l'usage de la notion centrale de code dans le contexte scientifique et culturel de l'immédiat après-guerre militait pour une telle convergence à court terme.

6. Claude Shannon, «The Mathematical Theory of Communication », Bell System Technical Journal, vol. 28, no 4, juillet/octobre 1948, p. 656-715; Warren Weaver, «The Mathematics of Communication ", Scientific American, vol. 181, n 1, juillet 1949, p. 11-15.

7. Max Delbrück, cité dans Steve J. Heims, The Cybernetics Group, Cambridge, Massachusetts, MIT Press, 1991, p. 95.

8. Erwin Schrödinger, What is Life?, Cambridge, United Kingdom, Cambridge University Press, 1944 .

9. Voir Steve J. Heims, The Cybernetics Group, p. 96, et Lily E. Kay, Who Wrote the Book of Life? A History of the Genetic Code, Stanford University Press, Stanford, 2000, p. 129. 
Le vocabulaire de l'information est en effet présent sous la forme de la notion de transcription dès le texte fondateur de la biologie moléculaire du gène, le fameux article de Crick et Watson annonçant leur modèle de structure pour l'ADN :

We wish to suggest a structure for the salt of deoxyribose nucleic acid (D.N.A.). This structure has novel features which are of considerable biological interest. [...] It has not escaped our notice that the specific pairing we have postulated immediately suggests a possible copying mechanism for the genetic material ${ }^{10}$.

Au sujet de cette dernière phrase, faussement énigmatique, Watson raconte dans son livre que Crick «désira développer notre note pour en tirer toutes les implications biologiques, mais finalement il se décida en faveur de la brièveté $^{11} \ldots »$

Le «dogme central » résume le principal credo de la biologie moléculaire à ses origines: le concept de base établit que

Once «information", has passed into protein it cannot get out again. In more detail, the transfer of information from nucleic acid to nucleic acid, or from nucleic acid to protein may be possible, but transfer from protein to protein, or from protein to nucleic acid is impossible. Information means here the precise determination of sequence, either of bases in the nucleic acid or of the amino acid residues in the $\operatorname{protein}^{12}$.

Le dogme central est à l'origine d'un glissement de sens de la notion d'information qui va être fécond pour l'avenir de la discipline:

In a single mastery stroke Crick encapsulated the ideology and experimental mandate of molecular genetics : genetic information, qua DNA, was both the origin and universal agent of all life (proteins) [...] But these biosemiotics entailed a deconstruction. In order to privilege nucleic acids as the sole source of biological information, this transformation had to tacitly subvert information from its scientific definition $[\ldots]$ the still-unbroken genetic code governed that metaphoric process of

10. Francis H. C. Crick, James D. Watson, «Molecular Structure of Nucleic Acids: A Structure for Deoxyribose Nucleic Acid», Nature, vol. 171, n 4356, 25 avril 1953, p. 737. 11. James D. Watson, La double hélice: compte rendu personnel de la découverte de l'ADN, trad. Henriette Joël, Paris, Hachette, 1984 [1968], p. 224.

12. Francis H. C. Crick, "On Protein Synthesis», dans Symposium of the Society of Experimental Biology, $\mathrm{n}^{\circ}$ 12, New York, Academic Press, 1958, p. 138-163, cité dans Lily E. Kay, Who Wrote the Book of Life?, p. 174. 
information transfer. Whether the latest decoding attempts had any validity, « only time will show», Crick concluded ${ }^{13}$.

Le dogme central acquit sa forme finale entre 1958 et 1961, avec la découverte du modèle de l'opéron (par l'équipe de Monod, Jacob et Wolf à l'institut Pasteur) et la collaboration internationale qui mena à la découverte de l'ARN messager (ARNm). C'est à partir du symposium tenu durant l'été au Brookhaven National Laboratory que les chercheurs commencèrent à douter de leur croyance antérieure selon laquelle l'ensemble de l'ADN coderait pour la synthèse protéique. À l'inverse, le modèle de l'opéron supposait une séparation du gène en «opérateur» et «opéron»: l'opéron est une unité d'expression génétique qui inclut des gènes structuraux et les éléments contrôlant leur expression, tandis que l'opérateur est une séquence d'ADN où se fixe une protéine qui régule négativement l'expression du gène (répresseur). Il s'agissait d'un premier pas vers une différenciation du fonctionnement du gène, qui allait ensuite mener à l'élaboration d'une métaphore textuelle pour le dogme central.

Ce modèle textuel aboutit à son tour au début du «décryptage du code génétique», durant la même année (1961), par Marshall W. Nirenberg et J. Heinrich Matthaei du National Institute of Health (NIH) à Bethesda au Maryland. Francis Crick conclut ainsi son discours lors de la réception de son prix Nobel, l'année suivante: «We are coming to the end of an era in molecular biology. If the DNA structure was the end of the beginning, the discovery of Nirenberg and Matthaei is the beginning of the end ${ }^{14}$. »

Éventuellement complété en 1966, le code est caractérisé par les spécificités suivantes (fig. 1):

- L'unité de codage de base (ou «mot») sur la chaîne d'ARNm est le codon, composé de trois nucléotides;

- Le code est dégénéré: plusieurs «mots » signifient la même chose;

- Le code est universel : il est identique pour tous les êtres vivants (d'où la métaphore du «livre de la vie»).

Même si la métaphore textuelle du code génétique comprenait en son cœur la notion d'information génétique, elle l'entendait elle aussi sur un mode métaphorique. En fait les relations entre la biologie moléculaire naissante et la cybernétique doivent être envisagées à partir de leur utilisation concurrente de

13. Lily E. Kay, Who Wrote the Book of Life?, p. 175.

14. Cité dans Lily E. Kay, Who Wrote the Book of Life?, p. 271. 
Fig. 1. La table du code génétique

\begin{tabular}{|c|c|c|c|c|c|}
\hline \multirow{2}{*}{$\begin{array}{c}\text { Ire position }^{\left(5^{\prime}\right)}\end{array}$} & \multicolumn{4}{|c|}{$2^{e}$ position } & \multirow{2}{*}{$\begin{array}{c}3^{e} \text { position } \\
\left(3^{\prime}\right)\end{array}$} \\
\hline & $\mathrm{T}$ & C & $A$ & G & \\
\hline \multirow{4}{*}{ u } & Phe & Ser & Tyr & cys & U \\
\hline & Phe & Ser & Tyr & Cys & C \\
\hline & Leu & Ser & STOP & STOP & $A$ \\
\hline & Leu & Ser & STOP & Trp & G \\
\hline \multirow{4}{*}{ C } & Leu & Pro & His & Arg & U \\
\hline & Leu & Pro & His & Arg & C \\
\hline & Leu & Pro & gin & Arg & $A$ \\
\hline & Leu & Pro & Gin & Arg & G \\
\hline \multirow{4}{*}{$A$} & Ile & Thr & Asn & Ser & $\mathrm{U}$ \\
\hline & lle & Thr & Asn & Ser & $\mathrm{C}$ \\
\hline & Ile & Thr & Lys & Arg & $A$ \\
\hline & Met & Thr & Lys & Arg & G \\
\hline \multirow{4}{*}{ G } & Val & Ala & Asp & Gly & U \\
\hline & Val & Ala & Asp & Gly & $C$ \\
\hline & Val & Ala & Glu & Gly & $A$ \\
\hline & Val & Ala & Glu & Gly & $G$ \\
\hline
\end{tabular}

Abréviations:

$\begin{array}{lllll}\text { U Uracile } & \text { Ala } & \text { Alanine } & \text { Leu Leucine } \\ \text { C Cytosine } & \text { Arg } & \text { Arginine } & \text { Lys Lysine } \\ \text { A Adénine } & \text { Asn Asparagine } & \text { Met } & \text { Méthionine } \\ \text { G Guanine } & \text { Asp Ac. Aspartique } & \text { Phe Phenylalanine } \\ & \text { Cys Cystéine } & \text { Pro Proline } \\ & \text { Gln Glutamine } & \text { Ser Sérine } \\ & \text { Glu Ac. Glutamique } & \text { Thr Thréonine } \\ & \text { Gly Glycine } & \text { Trp Thryptophane } \\ & \text { His Histidine } & \text { Tyr Tyrosine } \\ & \text { Ile Isoleucine } & \text { Val Valine }\end{array}$


la notion d'information, entendue dans des sens fondamentalement différents, pour ne pas dire opposés.

Pour la cybernétique et la théorie de l'information, toutes deux synthétisées en 1948, l'information est une quantité statistique: l'information conduite par un symbole donné est en relation avec la probabilité de son occurrence dans un message et non pas avec une quelconque signification du symbole. Comme l'a résumé Warren Weaver dans son célèbre article pour Scientific American, «le mot information est en rapport non pas tant avec ce que vous dites qu'avec ce que vous pourriez dire ${ }^{15} »$. Bref, la notion d'information de cette théorie ne comprend pas de dimension sémantique (fig. 2).

Fig. 2. Le schéma élémentaire de C. Shannon, 1949.

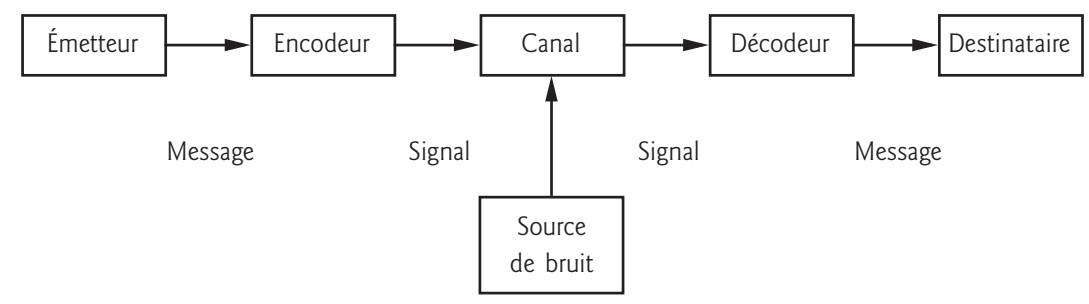

Il convient de noter que dans ce schéma, un signal, résultat de l'encodage d'un message, est transmis par un canal ou médium à un receveur qui le décode pour retrouver à destination le message initial. L'encodage est donc la traduction d'un message en un signal; le message est défini comme toute séquence discrète ou continue d'événements mesurables distribués dans le temps; le signal est une modulation ordonnée du médium (carrier). Le «code» est donc, dans ce cadre théorique, le principe (l'ensemble des règles) qui permet de transformer une séquence discrète d'événements en une modulation (un mouvement ordonné) du médium. Ce mouvement ordonné apparaît comme un ensemble déterminé de variations du médium, c'est-à-dire comme la transmission de différences. L'information est la mesure de la capacité du canal, une mesure probabiliste des choix entre ces alternatives.

15. Warren Weaver, «The Mathematics of Communication», Scientific American, vol. 181, $\mathrm{n}^{\circ}{ }^{1}$, juillet 1949, p. 11-15, cité dans Aline Pélissier, Alain Tête (éds.), Sciences cognitives. Textes fondateurs (1943-1950), trad. Aline Pélissier, Paris, Presses universitaires de France, 1995, p. 220. 
Après sa relecture de la linguistique à la lumière de la théorie de l'information (et particulièrement de la version du théoricien britannique Colin Cherry), l'apport de Roman Jakobson permit de boucler la synthèse d'un code génétique «verbal» ou «textuel». Cette convergence se matérialisa effectivement lors d'un débat télévisé ( «Vivre et parler») en septembre 1967, où Jakobson participa à une discussion avec Claude Lévi-Strauss et les biologistes François Jacob et Philippe L’Héritier. À cette occasion, et malgré les réticences de LéviStrauss et de L'Héritier, Jakobson affirma que:

Since the first time I encountered the linguistic terms in the literature of the biologists, I said to myself: one must check whether this is simply fashionable talk, a metaphoric usage, or whether there is here something exceedingly profound. I must say that the biologists' talk is totally legitimate from a linguistic view point and that one could go much further. What do the system of molecular genetics and the linguistic system have in common? Primarily it is this: that it is perhaps a most extraordinary thing and most important - it is the same architecture, these are the same principles of construction, a fully hierarchical principle ${ }^{16}$.

Jakobson excluait donc la possibilité d'un usage métaphorique des référents linguistiques en biologie moléculaire... à l'aide d'une métaphore architecturale! Par ailleurs, quelques années plus tôt, les rares chercheurs qui avaient tenté d'opérer une application stricte de la théorie de l'information à la biologie moléculaire et aux mécanismes de l'hérédité en étaient arrivés à des conclusions pour le moins mitigées, comme en témoigne cette citation de l'un d'entre eux, Henry Quastler, qui était aussi un des invités réguliers des rencontres Macy:

Information theory is very strong on the negative side, i.e. in demonstrating what cannot be done; on the positive side its application to the study of living things has not produced many results so far; it has not led to the discovery of new facts, nor has its application to known facts been tested in critical experiments. To date, a definitive and valid judgment of the value of information theory in biology is not possible $^{17}$.

Quelques années plus tard, à l'heure même du triomphe du décryptage du code (et donc de la métaphore linguistique), un autre chercheur concluait

16. Cité dans Lily E. Kay, Who Wrote the Book of Life?, p. 309.

17. Henry Quastler, «The Status of Information Theory in Biology », dans Hubert P. Yockey (dir.), Symposium on Information Theory in Biology, New York, Pergamon, 1956, p. 399-402, cité dans Lily E. Kay, Who Wrote the Book of Life?, p. 126. 
pareillement: "Workers have been aware of information theory and have made qualitative use of its concepts. No explicit, and especially no quantitative use of information theory has, however, been made in practice $^{18}$.» Il semble donc qu'il faille en conclure, comme Lily E. Kay, à l'usage métaphorique des notions de la théorie de l'information, et particulièrement de celle de «code génétique ».

Cependant, si le «code génétique » n’est que métaphoriquement un code au sens de la théorie de l'information, il n'en reste pas moins qu'il peut être considéré comme tel, malgré les oppositions de Lily E. Kay. Même si la biologie moléculaire a fait un usage métaphorique du code au sens de la théorie de l'information, celle-ci n'a pas pour autant le monopole de la définition du concept de code, tout au plus peut-elle le revendiquer dans le contexte de l’ingénierie des systèmes de télécommunication. Finalement, Lily E. Kay attribuait trop de crédit aux visées universelles de la cybernétique ${ }^{19}$. C'est l'argument de Richard Lewontin dans son compte rendu critique de l'ouvrage de Kay, lorsqu'il dit:

While claiming that we cannot really dispense with metaphors, she herself tries to do so by repeatedly saying that the DNA triplet-amino acid relation is merely a correlation. But that is surely wrong. DNA and amino acid sequences are not simply correlated, they are connected by a causal mechanism. And in the causal pathway, DNA sequence appears before the amino acid sequence. A good deal of discussion in the book is devoted to showing why the metaphors of «code ", "language », and «information » can be so misleading if taken as isomorphic with the phenomena of molecular genetics. This is especially a problem if these non-biological notions are taken in their modern analytic and scientific contexts. If «information » is the information of Shannon-Weaver information measures; if «language» is what Jakobson, Chomsky, and other linguists take it to be; if «code" is what the Enigma machine was meant to create; then as Kay so clearly shows, we are badly misled by applying these measures to DNA. But, as she says, «code", «language», and «information» are themselves metaphors, terms appropriated by science and technology and given special content for special purposes ${ }^{20}$.

18. Martynas Ycas, «Biological Coding and Information Theory», dans H. L. Lucas (dir.), The Cullowhee Conference on Training in Biomathematics, Raleigh, North Carolina State College, 1961, p. 245-58, cité dans Lily E. Kay, Who Wrote the Book of Life?, p. 126.

19. Geof Bowker, «How to Be Universal: Some Cybernetic Strategies, 1943-1970 », Social Studies of Science, vol. 23, 1993, p. 107-127.

20. Richard C. Lewontin, «Molecular Biology: In the Beginning Was the Word. A review of Who Wrote the Book of Life? A History of the Genetic Code, by Lily E. Kay ", Science, vol. 29, $\mathrm{n}^{\circ} 5507,16$ février 2001, p. 1263-64. 
Dans son livre intitulé La logique du vivant. Une histoire de l'hérédité, François Jacob concède lui aussi ce point. Tout en insistant sur le fait que «c'est aux algorithmes du monde vivant que s'intéresse aujourd'hui la biologie ${ }^{21}$ ", Jacob conclut en disant que, «enfermée dans son système d'explications, la science ne peut s'en évader. Aujourd'hui le mode est messages, codes, information. Quelle direction demain disloquera nos objets pour les recomposer en un espace neuf? » Jacob met ici le doigt sur la contingence des explications scientifiques vis à vis de cadres rhétoriques englobants, et, plus précisément, sur le rôle structurant que prennent certains concepts dans «l'air du temps». Comme le dit si bien Lily E. Kay, «the genetic code is "a period piece", a manifestation of the emergence of the information age ${ }^{22} »$.

Pour Lewontin comme pour Jacob, le nœud problématique se situe au niveau du mode de référence de la métaphore, c'est-à-dire des relations entre signifiant et signifié qu'elle autorise: «Il en est du code génétique comme d'une langue: même si elles sont dues au hasard, dès lors qu'elles sont instaurées, les relations entre "signifiant" et "signifié" ne peuvent changer ${ }^{23}$. » Cependant, Jacob semble prendre une position bien plus radicale que celle de Lewontin, lorsqu'il affirme qu' «une fois établi un système de relations, cellesci ne peuvent se modifier sous peine de faire perdre toute signification à ce qui en possédait déjà, de brouiller ce qui avait déjà valeur de message ${ }^{24}$ ». En fait, Jacob semble ici hésiter entre deux alternatives: (1) la référence est absolue, et toute remise en cause la détruit complètement, ou (2) la référence est relative, et une remise en cause apparaît comme une source de bruit qui «brouille» la signification.

Cette deuxième alternative me semble très porteuse, dans la mesure où il est alors envisageable d'introduire par ce fait un dynamisme dans l'explication, qui échappe complètement à la première alternative. En effet, opter pour un mode de référence fermé conduit à envisager un fonctionnement statique d'un code, analogue à celui d'une langue morte (c'est-à-dire qui n'est plus parlée). À l'inverse, insister sur le «brouillage» n'interdit pas de penser qu'un autre ordre, un nouveau mode de référence peut émerger du bruit. Dans une langue

21. François Jacob, La logique du vivant. Une histoire de l'hérédité, Paris, Éditions Gallimard, coll. «Tel», 1970, p. 321.

22. Lily E. Kay, Who Wrote the Book of Life?, p. 2.

23. François Jacob, La logique du vivant, p. 327.

24. François Jacob, La logique du vivant, p. 327. 
vivante, les mots changent de sens avec leur usage. Oublier ce fait conduit à figer la référence en convention institutionnelle, où le mot devient la chose, la carte le territoire. Le concept descriptif devient alors ontologique.

C'est bien dans ce sens qu'ont abondé les récentes analyses post-structuralistes de l'histoire de la biologie moléculaire, en se centrant sur la question de la performativité des représentations conceptuelles et/ou discursives. Lily E. Kay, par exemple, considère que le choix d'une représentation conceptuelle particulière lui confère en retour la capacité d'habiliter et de contraindre certaines pensées et actions ${ }^{25}$. Richard Doyle décrit, quant à lui, ce même type de phénomène sous le nom de «logiciel rhétorique»:

«Rhetorical software» marks my attempt to foreground the relational and material interactions that make possible the emergence of scientific statements. While highlighting the textuality of scientific practices, the term avoids a textual determinism: as any user of software knows, software is usable only within a network of hardware and - this is frequently overlooked — «wetware». The « rhetorical» side of this double formulation is an attempt to mark out what Deleuze and Guattari describe as the «fantastic» production of scientific statements, the inventive and imaginative taming of matter. Crucial to Deleuze and Guattari's claim is that it is only through such a disciplining that matter is actualized, brought onto the plane of reference. Theirs is thus a relational account of matter and language, and it is this notion of the relations between such «framing» and the actualization of scientific practices that I seek to mark out with «rhetorical software ${ }^{26} »$.

Pour en revenir à la question de la métaphore, il semble donc que la question centrale se situe au sujet de son mode de référence. Insister sur la limite de la métaphore ne nous informe pas beaucoup sur sa performativité : en rester à une simple dénonciation de la métaphore dans le cadre d'une épistémologie positive ne permet certainement pas de poser la question de la performativité métaphorique, c'est-à-dire de comprendre ce que fait la métaphore. Pour cela, il faut donc développer une autre épistémologie de la référence métaphorique, ce à quoi je vais m’employer maintenant.

25. Lily E. Kay, Who Wrote the Book of Life?, p. XVIII.

26. Richard Doyle, On Beyond Living: Rhetorical Transformations of the Life Sciences, Stanford, Stanford University Press, 1997, p. 6-7. 


\section{DES MOdES DE RÉFÉRENCE DE LA MÉTAPHORE}

Dans cette seconde partie, je partirai de cette instance spécifique d'usage de la métaphore de l'information en biologie moléculaire pour revenir sur le débat toujours d'actualité sur l'usage des métaphores en science. En contrastant diverses perspectives sur la métaphore et sur son rôle dans le discours scientifique, j’entends montrer que le réseau métaphorique du «livre de la vie» de la biologie moléculaire construit une vérité scientifique et philosophique contre l'illusion de la référence première ou littérale. En faisant ceci, je ne cherche pas à faire une synthèse des théories sur l'usage scientifique de la métaphore, mais plus simplement de présenter sommairement une perspective contemporaine qui échappe aux apories de la «vérité » et des «limites» de la métaphore.

Comme l'ont montré les historiens de la science Steven Shapin et Simon Schaffer, la naissance de la science expérimentale au XVII siècle s'accompagne aussi de l'invention des technologies littéraires du «témoignage virtuel », qui consistent en une véritable réforme de la prose à fins scientifiques. C'est dans ce cadre qu'intervint la première interdiction de la métaphore, comme figure emblématique du «style fleuri» :

Autre manifestation de modestie: la manière d'écrire «nue» dont Boyle se flattait. Il méprisait le style «fleuri»; son objectif était d'écrire «sur un mode plus philosophique que rhétorique». Ce style simple, austère, sans ornements (mais contourné) avait une fonction. Il servait à témoigner une fois encore, du dévouement du philosophe au bien de la communauté plutôt qu'à son prestige personnel. En outre le style «fleuri » était un obstacle au témoignage virtuel : c'était, disait Boyle, comme si on peignait «les lentilles d'une lunette ${ }^{27}$.

Comme le remarquent Shapin et Schaffer, cette position avait été bien décrite par des recherches antérieures aux leurs, comme en témoigne ce passage datant de 1932 :

The linguistic views of seventeenth-century scientists were characterized by a suspicion of language arising out of its association with the old science, which seemed to depend more upon words than upon nature, and out of a feeling that all instituted language tended to obscure rather than to describe realities. Linguistic defects were discovered in the imperfect meanings given to words, in the many meanings ascribed to a single word, in the figurative use of words, in the multiplication of words through synonyms, and in the number of irregularities and inconsistencies of gram-

27. Steven Shapin, Simon Schaffer, Leviathan et la pompe à air, Paris, Éditions La Découverte, 1993, p. 68. 
matical rules $[\ldots]$ what stylistic standards could naturally develop out of this conception of language? Certainly none other than those which almost invariably appear whenever the scientists touch upon style. There should be little figurative language, especially metaphors, which falsely describe action and things. There should be no verbal superfluity, but rather an economy of words sufficient to match exactly the phenomena. Words should be the plainest possible ${ }^{28}$.

Malgré cette «interdiction», certaines métaphores ont la peau dure et résistent, y compris chez ceux qui semblent les proscrire. Ainsi, la convergence post-moderne (post-Seconde Guerre mondiale) des savoirs techno-scientifiques et métaphysiques autour des disciplines de l'informatique et de la biologie moléculaire s'est beaucoup centrée sur une reprise des métaphores mécaniques de la modernité. Les métaphores modernes de l'homme-machine et plus généralement de la «créature artificielle» (golem et autres proto-cyborgs) ont été remises au goût du jour postindustriel grâce au vocabulaire cybernétique. C'est particulièrement dans les champs de l'intelligence artificielle (IA) et du génie génétique (sur le versant appliqué) que cette convergence s'est faite sentir, sous la forme d'un essai de redéfinition des frontières entre l'humain, l'animal et la machine. Cette convergence s'est traduite par l'apparition du trope du vivant comme machine cybernétique, avec des métaphores partielles autour du bipôle cerveau/ordinateur et corps/viande. Non sans susciter à quelques reprises de l'interdit initial, comme en témoignent ces réactions d'Allen Newell:

Metaphor is a particularly disarming way of arriving at truth. It invites the listener to find within the metaphor those aspects that apply, leaving the rest as the false residual, necessary to the essence of metaphor. And since the metaphor is always, by the linguistic turn, within the listener, the invitation is to find within oneself some truth that fits $[\ldots]$ It is clearly wrong to treat science as metaphor, for the more metaphorical, the less scientific ${ }^{29}$.

Les philosophes de la science ont beaucoup débattu sur la place de la métaphore (et des modèles) dans la pratique scientifique moderne et postmoderne. À la suite du travail fondateur de Max Black ${ }^{30}$, les débats ont princi-

28. Richard Foster Jones, « Science and Language in England in the Mid-Seventeenth Century ", Journal of English and German Philology, vol. 31, 1932, p. 315-331 et p. 328-329.

29. Allen Newell, « Metaphors for Mind, Theories of Mind: Should the Humanities Mind? », dans James J. Sheehan and Morton Sosna (dirs.), The Boundaries of Humanity. Humans, Animals, Machines, Berkeley, California University Press, 1991, p. 160.

30. Max Black, Models and Metaphors, Ithaca, Cornell University Press, 1962. 
palement porté sur le caractère heuristique de la métaphore dans la production de la théorie scientifique, ainsi que sur les «limites» de l'analogie (comme en témoignent encore les remous autour de «l'affaire Sokal»). Certains, comme Richard Boyd, insistent sur le caractère utilitariste de la métaphore qui fonctionne comme une catachrèse lorsqu'elle permet la création d'un registre sémantique par importation dans un champ nouveau du vocabulaire d'un champ déjà balisé ${ }^{31}$. Mais la catachrèse signifie aussi l'utilisation abusive d'un mot au delà de son sens habituel. En ce sens, elle constitue un des mécanismes élémentaires de tout trope.

L'usage de la métaphore en sciences repose sur la question des rapports entre différentes dichotomies telles que littéraire/scientifique, littéral/figuré, individuel/collectif; toutes ces dichotomies illustrent des aspects particuliers de la problématique de la création, traduite dans une logique de la découverte et de son exposition. Pour ma part, je partirai du principe que la métaphore se situe à l'interface de ces dichotomies, plutôt que d'un côté ou d'un autre des oppositions qu'elles incarnent. Ainsi, la métaphore se situe entre la science et la littérature, le sens littéral et le sens figuré, la création individuelle ou collective. Elle définit donc un site stratégique pour étudier leur articulation, leurs points de passage. C'est en ce sens que je m'accorde avec la réflexion sur la métaphore proposée par Paul Ricœur :

Une nouvelle problématique émerge [...] elle ne concerne plus la forme de la métaphore en tant que figure du discours focalisé sur le mot; ni même seulement le sens de la métaphore en tant qu'instauration d'une nouvelle pertinence sémantique; mais la référence de l'énoncé métaphorique en tant que pouvoir de «redécrire » la réalité $[. .$.$] La métaphore se présente alors comme une stratégie de discours qui,$ en préservant et développant la puissance créatrice du langage, préserve et développe le pouvoir heuristique déployé par la fiction ${ }^{32}$.

Finalement, le refus de ces dichotomies me conduit plutôt, comme Paul Ricœur, à interroger l'usage de la métaphore en tant que stratégie de discours, dans la perspective de ses modes de référence:

31. Richard Boyd, «Metaphor and Theory Change: What is "Metaphor" a Metaphor for? », dans Andrew Ortony (dir.), Metaphor and Thought, Cambridge, Massachusetts, Cambridge University Press, 1979.

32. Paul Ricœur, La métaphore vive, Paris, Éditions du Seuil, coll. «L'ordre philosophique », 1975, p. 10. 
[...] La suspension de la référence $[\ldots]$ est la condition négative pour que soit dégagé un mode plus fondamental de référence [...] la manière même dont le sens métaphorique se constitue donne la clé du dédoublement de la référence [...] Le sens d'un énoncé métaphorique est suscité par l'échec de l'interprétation littérale de l'énoncé [...] L'autodestruction du sens sous le coup de l'impertinence sémantique, est seulement l'envers d'une innovation de sens au niveau de l'énoncé entier [...] L'interprétation métaphorique, en faisant surgir une nouvelle pertinence sémantique sur les ruines du sens littéral, suscite aussi une nouvelle visée référentielle, à la faveur même de l'abolition de la référence correspondant à l'interprétation littérale de l'énoncé 33 .

Cette logique de l'usage (référentiel) de la métaphore me conduit aussi à suivre les pas de Lakoff et Johnson, dans une perspective expérientielle: le pouvoir heuristique de la fiction auquel Ricœur fait allusion n'est pas seulement une affaire de compréhension abstraite d'un jeu sur les mots et donc d'un rapport sémantique, mais bien un rapport pragmatique renvoyant à un domaine d'expérience, entre la pensée et l'action. Cette dernière dichotomie me conduit à envisager la métaphore (scientifique) comme une fiction opérationnelle, un processus ouvert sur l'expérience et la production du monde dans et par le discours. Comme le disent Lakoff et Johnson, «things in the world do play a role in constraining our conceptual system. But they play this role only through our experience of them ${ }^{34}$ ».

Au total, cette perspective sur la pragmatique de la métaphore du «code génétique » me conduit à insister sur les aspects suivants:

- le sens de cette métaphore en biologie moléculaire se construit sur la destruction du sens littéral fourni par la théorie de l'information et sa définition formelle de la notion de code;

- cette destruction de la référence première réintroduit contre elle une sémantique du code et des transformations qu'il permet: le «code génétique» devient ainsi l'ensemble des règles de conservation et de transformation de la spécificité génétique pour la synthèse protéique;

- cette référence seconde rouvre le champ discursif vers une heuristique de la transmission et de la communication, du patrimoine et de l'appropriation du gène;

33. Paul Ricœur, La métaphore vive, p. 288-89.

34. Georges Lakoff, Mark Johnson, Metaphors we live by, Chicago, University of Chicago Press, 1980, p. 154 . 
- cette heuristique s'ouvre alors sur un nouveau champ de pratique et d'expérience pour la nouvelle discipline, et habilite ainsi la construction d'un monde nouveau.

La métaphore du code génétique dans le répertoire conceptuel de la biologie moléculaire des années 1950-1960 apparaît donc au centre d'un dispositif discursif et disciplinaire qui, à l'interface des théories cybernétiques fondatrices (littéral) et du sens commun (figuré), habilite la production d'un monde expérimental: cette habilitation construit en retour son propre référent.

Information - as meaning and commodity — came to signify the privileged status of DNA as «master molecule». Emptied of its technical content, it actually became a metaphor of a metaphor, a signification without a referent. This, however, did not diminish its scientific and cultural potency ${ }^{35}$.

Donc, contrairement à ce que dit Kay ici, la métaphore du code génétique n’est pas sans référent, même si elle peut être considérée comme la métaphore d'une métaphore, au sens (plus explicite à mon goût) d'une référence seconde, qui ne lui est d'ailleurs pas propre, si on en croit Ricœur. Par contre, la spécificité de cette métaphore, c'est sa manière bien particulière de boucler en l'ouvrant la boucle de la référence sur le sens quasi magique, préscientifique de la fiction fondatrice du verbe: c'est dans cette perspective que l'on pourra interpréter sa situation systématique dans le réseau métaphorique du «secret du livre de la vie», avec ses élans hermétiques de révélation ultime parce qu'originelle... Dans l'alliance de ces deux termes, on retrouve aussi ce que Gilbert Simondon appelle une médiation primitive, avant son « déphasage » en technicité et religiosité 36 .

\section{L’ADN NON CODANT OU JUNK: UNE PERSPECTIVE SÉMIOTIQUE SUR LA MÉTAPHORE DU CODE GÉNÉTIQUE}

De manière à concrétiser à rebours l'argument théorique concernant la valeur de vérité de la métaphore, je proposerais dans cette troisième et dernière partie de revenir sur un aspect lié à la métaphore du «livre de la vie », en développant au sujet de la partie non codante de l'ADN une perspective sémiotique en

35. Lily E. Kay, Who Wrote the Book of Life?, p. 127.

36. Gilbert Simondon, Du mode d'existence des objets techniques, Paris, Aubier, $195^{8}$. 
phase avec la théorie précédente des modes de référence métaphorique. En fait, je me propose de tester l'hypothèse d'un mode de référence ouvert de la métaphore en examinant une de ses limites, ce que Newell qualifiait de «false residual». Si l'hypothèse d'un mode de référence ouvert peut soutenir un tel test, le prétendu faux résidu pourrait alors apparaître comme un second souffle possible pour la métaphore du code génétique.

Depuis 1977, les biologistes moléculaires ont découvert que les gènes humains, comme ceux de tous les eucaryotes (ou organismes supérieurs), pouvaient être interrompus par des séquences non codantes (ou introns) pour la synthèse des protéines. Cette partie non fonctionnelle dans les limites des connaissances de l'époque a vite été qualifiée de «junk DNA» - improprement traduit en français par l'expression «ADN déchet ${ }^{37}$ ».

Au moment de cette découverte, la référence primaire de la métaphore du " code génétique » était si bien installée, même si elle était «erronée », qu’elle ne pouvait être remise en cause: l'ADN est le médium de la transmission du patrimoine génétique de l'individu, l'arrangement de ses bases est un message dans un code digital qui constitue la «mémoire génétique » de l’individu. Or, nous savons maintenant, grâce au décryptage du génome, que 97 à $99 \%$ des séquences de bases de l'ADN des organismes supérieurs ne signifient rien pour la synthèse protéique... Est-ce pour autant que ces séquences ne «veulent rien dire» dans le cadre de la métaphore du code?

Dans le reste du présent article, je tenterai donc de répondre à cette question en envisageant le statut du non-codant vis-à-vis de la métaphore du code, en le considérant tour à tour à la lumière des approches sémiotiques d'Umberto Eco, de Roland Barthes et de Jean-Pierre Faye. Le choix de ces trois perspectives différentes sur la métaphore du code génétique provient, dans chaque cas, du couplage d'une perspective sémiotique spécifique avec une théorie contemporaine sur la signification du junk DNA.

La réponse standard à la question de l'éventuelle fonction ou signification de l'ADN non codant s'inscrit dans une perspective évolutionniste néodarwinienne qui l'intègre fort bien dans l'économie générale du réseau métaphorique du «livre de la vie». Ainsi, l'ADN est lui-même souvent assimilé à un livre,

37. «Most of this enormous, silent genetic majority has long been thought to have no real function - hence its name: "junk DNA". But one researcher's trash is another researcher's treasure. » (Rachel Nowak, "Mining treasures from "junk DNA" ", Science, vol. $263, n^{\circ} 5147$, février 1994, p. 608) 
comme sur le site du Human Genome Project, où il est comparé à " 200 annuaires téléphoniques de Manhattan»(de 1000 pages chacun). On nous informe aussi qu'il faudrait 26 ans pour le lire... dans le cadre de cette métaphore, le junk DNA est envisagé comme l'ensemble des numéros des abonnés qui auraient changé d'adresse (de tous les temps!). Mais cette métaphore est plus ample que cette simple analogie. Plus généralement, la perspective orthodoxe héritée du dogme central continue à considérer que si certaines parties de l'ADN ne codent pas pour la synthèse protéique, c'est qu'elles n’ont pas de fonction du tout, qu'elles ne sont que les «vestiges d'anciennes informations ${ }^{38}$. »

En fait, cette première caractérisation du junk comme ensemble fossilisé s'inscrit dans la perspective la plus directe de l'application originelle de la théorie de l'information. Dans ce cadre, la mutation ponctuelle est à l'origine de l'évolution mais aussi de ses vestiges non fonctionnels: c'est la source de bruit. Ce trope apparaît régulièrement dans les discours sur le junk: «Biolinguists are trying to find a method for picking up the core three percent from the biochemical background noise and they are trying to spot the words without having to worry about what those words say ${ }^{39}$. "

Il est possible d'envisager cette perspective à partir de la théorie des codes d'Umberto $\mathrm{Eco}^{40}$, qui reprend le modèle originel de la théorie de l'information en l'amendant de manière à introduire la notion de s-code et en caractérisant le «code génétique» comme un s-code du type (c), «ensemble de réponses comportementales du receveur». Eco reste ainsi au plus proche de la visée structuraliste initiale de Jakobson.

Eco étend en effet le concept de «code» de la théorie de l'information à quatre types de phénomènes:

a) un ensemble de signaux gouvernés par des lois combinatoires internes, ce qu'il appelle un système syntaxique;

b) un ensemble d'états qui sont pris en compte en tant qu'ensemble de notions au sujet de ces états et qui peuvent devenir un ensemble de contenus communicables, ce qu'il appelle un système sémantique;

38. Werner R. Loewenstein, The Touchstone of Life: Molecular Information, Cell Communication and the Foundations of Life, Oxford, Oxford University Press, 1999, p. 93.

39. Nathalie Angier, «Biologists Seek Words in DNA's Unbroken Text», New York Times, 9 juillet 1991, p. C1.

40. Umberto Eco, A Theory of Semiotics, Bloomington, Indiana University Press, 1976 , p. 36-38. 
c) un ensemble de réponses comportementales possibles de la part du destinataire, ce que je serais tenté d'appeler un système pragmatique;

d) une règle couplant certains éléments du système (a) avec certains éléments du système (b) ou (c).

En considérant le code génétique comme un s-code du type (c), Eco considère donc la séquence des acides aminés (dans le cytoplasme) comme un ensemble de réponses comportementales du destinataire. Mais l'ARN-messager peut tout aussi bien apparaître comme une modulation du médium de l'hérédité : la transcription de l'ADN en ARNm par épissage des parties non codantes (junk) et la permutation des bases $\mathrm{T}$ (Thymine) en U (Uracile) fait émerger le signal par un type de modulation que l'on peut qualifier de digitale (ou discrète). En ce sens, Eco néglige que l'on puisse même caractériser le code génétique comme un code au plein sens du terme (d), c'est-à-dire comme une règle couplant le système syntaxique de la transcription (a) au système pragmatique (c) de la traduction des codons de l'ARNm en séquence d'acides aminés (fig. 3).

Fig. 3. Les équivalences du code génétique

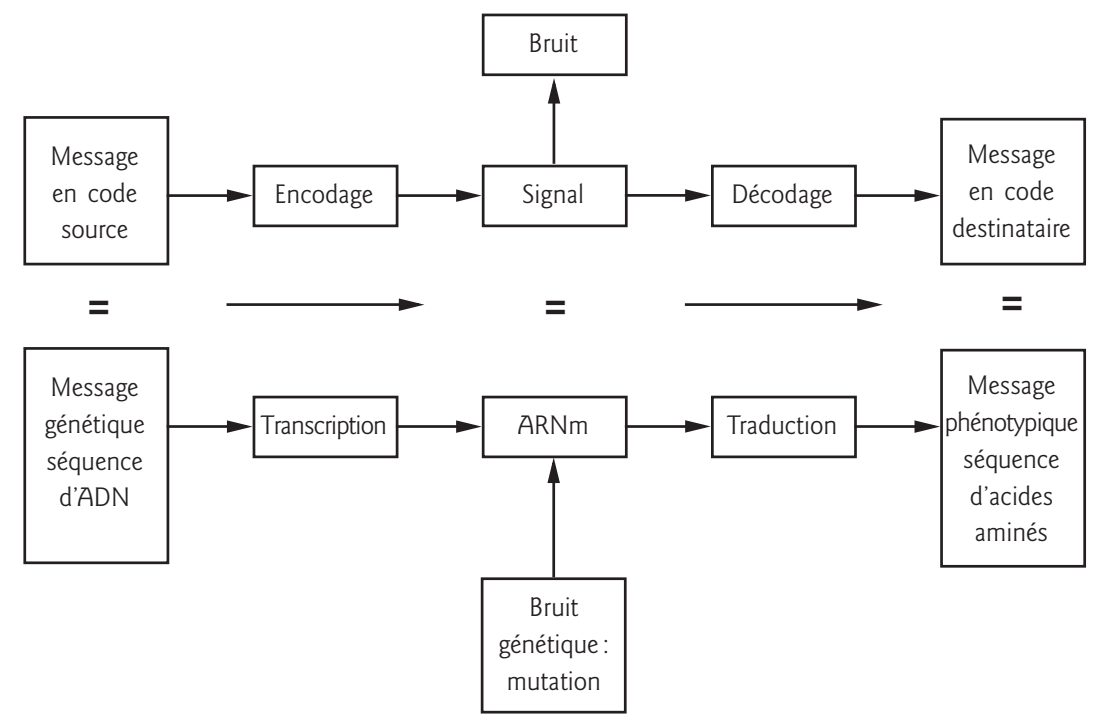


Cependant cette perspective, à mes yeux, a le désavantage de fermer le mode de référence de la métaphore du code génétique sur sa référence première: en assimilant métaphoriquement l'ADN au médium de l'hérédité, elle en arrive à considérer que l'ADN ne peut être que cela. En d'autres termes, la description permise par la métaphore est devenue ontologie. Une seconde perspective sémiotique va maintenant me permettre de rouvrir le mode de référence métaphorique du code génétique en évitant de transformer la référence première en ontologie.

En effet, si je poursuis la description sémiotique de l'ADN, je peux tout aussi bien caractériser le junk d'ensemble de détails insignifiants porteurs d'un effet de réel, tel qu'analysé par Roland Barthes ${ }^{41}$. Dans cette perspective, les parties non codantes de l'ADN apparaissent comme «les résidus irréductibles de l'analyse fonctionnelle»: en d'autres termes, ils apparaissent comme ce qui résiste à la signification unique de l'ADN vis-à-vis d'une fonction de codage orientée vers la synthèse protéique. Leur présence ne fait que confirmer la narration orthodoxe, mécanique et matérialiste, de la biologie moléculaire standard. Comme l'a montré Barthes pour une analyse textuelle, la présence de tels détails insignifiants pour la narration n'a pas d'autre effet que de rendre celleci plus réaliste:

Sémiotiquement, le «détail concret» est constitué par la collusion directe d'un référent et d'un signifiant; le signifié est expulsé du signe, et avec lui, bien entendu, la possibilité de développer une forme du signifié, c'est-à-dire, en fait, la structure narrative elle même [...] c'est là ce que l'on pourrait appeler l'illusion référentielle; la vérité de cette illusion est celle-ci : supprimé de l'énonciation réaliste à titre de signifié de dénotation, le «réel»y revient à titre de signifié de connotation; [...] c'est la catégorie du «réel» (et non ses contenus contingents) qui est alors signifiée; autrement dit, la carence même du signifié au profit du seul référent devient le signifiant même du réalisme: il se produit un effet de réel, fondement de ce vraisemblable inavoué qui forme l'esthétique de toutes les œuvres courantes de la modernitét2.

Dans ce sens, les parties non codantes de l'ADN résistent à l'équation ontologique de l'ADN au médium de l'hérédité, une résistance qui, comme le dit Barthes, «confirme la grande opposition mythique du vécu (du vivant) et de l'intelligible ${ }^{43} »$. Par rapport à la perspective sémiotique présentée antérieure-

41. Roland Barthes, «L'effet de réel », Communications, n 11, 1968, p. 84-89.

42. Roland Barthes, «L'effet de réel», p. 88.

43. Roland Barthes, «L'effet de réel», p. 87. 
ment, une telle perspective a le mérite de rappeler que la métaphore du code génétique, dans son mode primaire de référence, consiste en un récit qui n'en est que plus réaliste à mesure qu'une partie du réel — de l'ADN — semble lui échapper. L'inclusion dans le récit de détails insignifiants pour la narration rend donc paradoxalement celle-ci plus réaliste: la prise en compte des séquences non codantes en tant que bruit rend plus réaliste la métaphore d'un code qui organiserait l'ADN en fonction de la synthèse protéique. L'ADN apparaît alors principalement - et non plus uniquement - comme le médium de l'hérédité.

Mais l'effet de réel une fois concédé, il nous faut alors envisager l'effet de récit. Si les détails insignifiants rendent la narration plus «réaliste», sa signification peut aussi produire le réel. En cette inversion, je suis donc la circulation décrite par Jean-Pierre Faye, depuis son récit hunique ${ }^{44}$ jusqu'au langage meurtrier $^{45}$, depuis «l'envoi » du premier:

Sans exception, ces textes sont réponse à quelqu'un (qui manque ici), à une demande ou circonstance (qu'on ne voit pas). Mais en même temps ils se répondent, les uns aux autres. Les mettre ensemble ne vise qu'à laisser voir une certaine figure, que, par bribes et retours, ils ont dessinée: une certaine narration au deuxième degré. Elle peut se voir de biais. Et si on l'observe trop fixement? Elle doit se brouiller, car sans doute elle rit. Car cette figure est le tracé d'une précise et périlleuse fonction qui n'arrête pas de bouger ${ }^{46}$.

jusqu’à la formule elliptique du dernier :

En passant et comme à son insu ou distraitement, Malby a fait apparaître, à propos précisément de l'irruption du peuple des Huns sur la scène de l'histoire, ce qu'il faudra désormais nommer l'effet de récit: certains récits admet-il, ont changé la face ou la forme des nations. L'histoire réelle a pu être transformée par la façon de conter - et de compter. Rapporter le récit, c'est aussi donner le pouvoir du Rapport: de la mise en rapport et de la mesure de celui-ciri ${ }^{47}$

Le premier envoi encode à la fois la thèse et la carte de mon récit comme autant de réponses à quelqu'un qui manque, comme un destinataire en quête d'un émetteur ou qui plutôt aurait appris à s'en passer (une sorte de sevrage

44. Jean-Pierre Faye, Le récit hunique, Paris, Éditions du Seuil, 1967.

45. Jean-Pierre Faye, Le langage meurtrier, Paris, Hermann, coll. «Savoir», 1996.

46. Jean-Pierre Faye, Le récit hunique, p. 7.

47. Jean-Pierre Faye, Le langage meurtrier, p. 2. 
moderne); le second les récapitule en une formule ramassée - tout est dans l'italique. Ici placés en pivot sans cesse retardé, ils permettent de faire basculer enfin mon récit dans un deuxième mode de référence, non pas décrété abstraitement, mais bien plutôt conté. Le tout pour une figure qui ne peut se voir que de biais, et qui rit. Avec le même sens de l'humour que celui de l'aveugle bibliothécaire de Buenos Aires, qui me fournit une épigraphe tardive:

Plus d'une fois je criai aux murs qu'il était impossible de déchiffrer un tel texte. Insensiblement, l'énigme concrète qui m'occupait me tourmenta moins que l'énigme générique que constitue une sentence écrite par un Dieu: "Quelle sorte de sentence, me demandais-je, pourrait formuler une intelligence absolue? » Je réfléchis que, même dans les langages humains, il n'y a pas de proposition qui ne suppose l'univers entier ${ }^{48}$.

Le récit du code génétique détruit la référence littérale de la métaphore cybernétique, mais en la préservant comme amorce d'un récit originel. De cette origine, amorçage - bootstrap - il ne restera rien qu'une injonction sans cesse réitérée : reboot! Du dogme central d'un codage à sens unique, il ne reste déjà plus que la possibilité toujours entretenue d'un (autre) code dans le code, un surcode, un métacode, un supracode, etc. Même les développements les plus orthodoxes du dogme originel ont déjà repris l'inversion, tout en préservant, il est vrai, l'essentiel du dogme, la fonction matérielle. Richard Dawkins ${ }^{49}$ n'a-t-il pas reçu l'approbation de Sir Francis Crick himself, lorsqu'il a proposé (dès 1976) de considérer le junk comme «égoïste ", suivant en cela le fameux aphorisme de Samuel Butler: "la poule n'est simplement que le moyen pour un ouf de faire d'autres œufs»?

D'autres n'ont pas été aussi conservateurs, et depuis 1994, de nombreuses fonctions ont en effet été imaginées ou démontrées pour l'ADN non codant. Ces fonctions s'inscrivent dans le réseau métaphorique du «code génétique » et nous invitent à lui trouver à rebours un «nouveau souffle». La boucle de la référence seconde de la métaphore du code peut se redoubler dans le cadre d'une construction sémiotique qui re-présenterait le junk DNA sous la forme d'un autre code, pour l'instant indéchiffrable, ce que l'on pourrait donc résumer ainsi (en reprenant le vocabulaire des télécommunications): et si l'ADN

48. Jorge Luis Borges, «L'écriture du Dieu», dans L'Aleph, (Euvres complètes, tome 1, trad. Paul Bénichou, Sylvia Bénichou-Roubaud, Jean Pierre Bernès, Roger Caillois et al., Paris, Éditions Gallimard, coll. «La Pléiade», 1993 [1949], p. 633.

49. Richard Dawkins, The Selfish Gene, Oxford, Oxford University Press, 1976. 
était un médium multiplexe, capable de conduire (de transmettre) à la fois les messages de la synthèse protéique et d'autres messages?

Cette polyfonctionnalité, ou cette multimodalité, permet d'envisager «d'autres langages, d'autres mondes » avec lesquels l'ADN pourrait nous mettre en contact. À l'heure de l'ordinateur intermédial (World Wide Web), cette métaphore filée fait entrer la signification dans le domaine de la télécommunication, de la communication à travers le temps et la distance, et même, pourquoi pas... le multiverse quantique. En témoigne la récente thèse de Johnjoe McFadden, qui réactualise la référence originelle à Schrödinger en retournant à l'intuition quantique (son premier chapitre s'intitule comme le livre du physicien, What is Life?):

The quantum Zeno effect would no longer be able to nail the sequence to a classical reality, allowing the gene to descend into the quantum world. Thereafter, the gene would have continued its drift within the quantum multiverse $[\ldots]$ of genes sequences $[\ldots]$ A significant portion of the genomes of all organisms may $[\ldots]$ be capable of this kind of quantum sequence drift [...] Perhaps as much as ninety percent of our own DNA may be junk sequences. This will be invisible to the cell's quantum-measuring devices, allowing their mutational events to drift unnoticed into the quantum realm ${ }^{50}$.

En réponse à un courrier électronique où je lui demandais l'origine de cette notion du junk comme ensemble des séquences de l'ADN capable de drift quantique, McFadden me répondit laconiquement: «I'm afraid this is entirely (informed) speculation. My thesis is that DNA may drift into the quantum world whenever it becomes sufficiently isolated from the environment. Junk DNA seems to be the most likely to be isolated. »

Jeremy Narby, dans son ouvrage intitulé The Cosmic Serpent: DNA and the Origins of Knowledge, présente une autre hypothèse, et imagine - à l'aide d'un puissant cocktail psychotrope amazonien - , que «the global network of DNAbased life emits ultra-weak radio waves [...] as the aperiodic crystal of DNA is shaped like two entwined serpents, two ribbons, a twisted ladder, a cord, or a vine, we see in our trances serpents, ladders, cord, vines, spirals, crystals, and so on $^{51}$.» Narby insiste sur le fait que l'appellation même de junk DNA est

50. Johnjoe McFadden, Quantum Evolution: The New Science of Life, New York, Norton, 2000, p. 268.

51. Jeremy Narby, The Cosmic Serpent: DNA and the Origins of Knowledge, New York, Putnam, 1998, p. 116. 
symptomatique de ce qu'il appelle la «cowboy science», caractérisée par sa capacité à minimiser l'inconnu.

Faute d'espace, je me bornerai ici à ces brèves allusions à ces intuitions, hypothèses et théories construites sur un mode de référence ouvert de la métaphore du code génétique. Elles feront l'objet de publications futures. Je terminerai simplement en constatant qu'il est évidemment inutile de se demander si Narby ou McFadden ont «raison »... Certains se chargeront sûrement de les ridiculiser en les taxant d'auteurs de science-fiction. Pour ma part, je pense que l'on peut dire, sans tomber dans l'illusion de la référence, qu'ils n’ont sûrement pas plus tort ou raison a priori que ceux qui voient dans l'ADN un quelconque «code». Je parierais même que quelque part dans leurs fictions se cachent les germes des savoirs scientifiques de demain.

Si le code génétique est une catachrèse, ou mieux, le nom propre d'une référence ouverte et itérative (et potentiellement infinie, une semiosis), c'est grâce à l'isomorphisme du verbe, qui permet l'hybridation (les passages et les croisements) entre des savoirs hyper spécialisés (biologie moléculaire, informatique, linguistique, physique quantique, etc.) qui sont autant de quêtes à jamais inachevées. Je gage ici que la sémiotique (narrative) pourra nous permettre de décrire et d'expliciter les ressorts de ces quêtes, les formes de ces récits.

Mais plus qu'un simple pari heuristique, je pense qu'il faut voir dans le fonctionnement métaphorique de la construction de ces discours un premier pas vers la définition de nouvelles pratiques, de l'expérience des nouveaux mondes qu'ils contribuent à produire. Le mode de référence ouvert de la métaphore du code génétique apparaît donc comme un système sémiotique dont le référent évolue en phase avec les frontières des savoirs spécialisés (et parfois à leur marge).

Comme le notait Hermann Hesse en épigraphe à son Jeu des perles de verre:

Il n'est rien qui échappe davantage à la représentation verbale et qu'il soit pourtant plus nécessaire de mettre sous les yeux des gens que de certaines choses, dont l'existence n'est ni démontrable, ni vraisemblable, mais qui, du fait même que des hommes pieux et consciencieux en traitent quasiment comme si elles existaient, approchent un peu de l'être et de la possibilité de naître ${ }^{52}$.

52. Hermann Hesse, Le jeu des perles de verre, trad. Jacques Martin, Paris, CalmannLévy, 1955 [1943], p. 19. 